\title{
RETHINKING
}

FINANCE IN THE

FACE OF NEW

CHALLENGES

Edited by David Bourghelle,

Roland Pérez and Philippe Rozin

CRITICAL STUDIES ON

CORPORATE RESPONSIBILITY,

GOVERNANCE AND SUSTAINABILITY

VOLUME 15 


\section{RETHINKING FINANCE IN THE FACE OF NEW CHALLENGES}




\section{CRITICAL STUDIES ON CORPORATE RESPONSIBILITY, GOVERNANCE AND SUSTAINABILITY}

\section{Series Editor: William Sun}

\section{Recent Volumes:}

Volume 1: Reframing Corporate Social Responsibility: Lessons from the Global Financial Crisis _ Edited by William Sun, Jim Stewart and David Pollard

Volume 2: $\quad$ Finance and Sustainability: Towards a New Paradigm? A Post-Crisis Agenda _ Edited by William Sun, Celine Louche and Roland Perez

Volume 3: $\quad$ Business and Sustainability: Concepts, Strategies and Changes _ Edited by Gabriel Eweje and Martin Perry

Volume 4: Corporate Social Irresponsibility: A Challenging Concept _ Edited by Ralph Tench, William Sun and Brian Jones

Volume 5: Institutional Investors' Power to Change Corporate Behavior: International Perspectives _ Edited by Suzanne Young and Stephen Gates

Volume 6: Communicating Corporate Social Responsibility: Perspectives and Practice _ Edited by Ralph Tench, William Sun and Brian Jones

Volume 7: $\quad$ Socially Responsible Investment in the 21st Century: Does It Make a Difference for Society? _ Edited by Celine Louche and Tessa Hebb

Volume 8: Corporate Social Responsibility and Sustainability: Emerging Trends in Developing Economies _ Edited by Gabriel Eweje 
Volume 9: The Human Factor in Social Capital Management: The OwnerManager Perspective _ Authored by Paul Manning

Volume 10: Finance Reconsidered: New Perspectives for a Responsible and Sustainable Finance _ Edited by Bernard Paranque and Roland Perez

Volume 11: Finance and Economy for Society: Integrating Sustainability _ Edited by Sharam Alijani and Catherine Karyotis

Volume 12: The Critical State of Corporate Social Responsibility in Europe Edited by Ralph Tench, Brian Jones and William Sun

Volume 13: Negative Interest Rates: The Black Hole of Financial Capitalism _ Authored by Jacques Ninet

Volume 14: The Sustainability Debate: Policies, Gender and the Media Edited by Martina Topić and George Lodorfos 
This page intentionally left blank 


\section{EDITORIAL ADVISORY BOARD}

Sharam Alijani

NEOMA Business School, France

Fabienne Alvarez

University of Antilles and Guyane

Pointe-à-Pitre, France

Ralph Bathurst

Massey University, New Zealand

Lawrence Bellamy

The University of Sunderland, UK

Robert Chia

Glasgow University, UK

Blanaid Clarke

The University of Dublin, Ireland

Thomas Clarke

University of Technology Sydney,

Australia

Barry A. Colbert

Wilfrid Laurier University, Canada

Alexandre Di Miceli da Silveira

University of São Paulo (USP), Brazil

Gabriel Eweje

Massey University, New Zealand

Hershey H. Friedman

Brooklyn College of the City University of New York, USA

Adrian Henriques

Middlesex University Business School, $U K$

Øyvind Ihlen

University of Oslo, Norway

Lin Jiang

Renmin University of China, China

Catherine Karyotis

Neoma Business School, France

Henri Kuokkanen

Institut Paul Bocuse, France

Elizabeth C. Kurucz

University of Guelph, Canada

Richard W. Leblanc

York University, Canada
Céline Louche

Audencia Business School, France

Guler Manisali-Darman

Principal of the Corporate Governance and Sustainability Center, Turkey

Paul Manning

University of Chester, UK

James McRitchie

Corporate Governance (CorpGov.net), USA

Abagail McWilliams

University of Illinois at Chicago, USA

Roland Pérez

University Montpellier I, France

Yvon Pesqueux

Conservatoire National des Arts et

Metiers, France

Lars Rademacher

Macromedia University of Applied

Sciences, Germany

Simon Robinson

Leeds Beckett University, UK

Greg Shailer

The Australian National University,

Canberra, Australia

John Shields

The University of Sydney Business

School, Australia

Jim Stewart

Liverpool John Moores University,

$U K$

Peter Stokes

De Montfort University, UK

Ralph Tench

Leeds Beckett University, UK

Christoph Van der Elst

Tilburg University, The Netherlands

Wayne Visser

Antwerp Management School, Belgium

Suzanne Young

La Trobe University, Australia 
This page intentionally left blank 
CRITICAL STUDIES ON CORPORATE RESPONSIBILITY, GOVERNANCE AND SUSTAINABILITY VOLUME 15

\section{RETHINKING FINANCE IN THE FACE OF NEW CHALLENGES}

EDITED BY

DAVID BOURGHELLE

University of Lille, France

\section{ROLAND PÉREZ}

University of Montpellier, France

And

\section{PHILIPPE ROZIN}

University of Lille, France

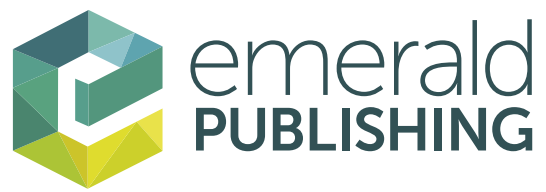

United Kingdom - North America - Japan India - Malaysia - China 
Emerald Publishing Limited

Howard House, Wagon Lane, Bingley BD16 1WA, UK

First edition 2021

Editorial matter and selection (C) 2021 David Bourghelle, Roland Pérez and Philippe Rozin. Published under exclusive licence by Emerald Publishing Limited.

Individual chapters copyright $(\odot) 2021$ the authors. Published under exclusive licence by Emerald Publishing Limited.

\section{Reprints and permissions service}

Contact: permissions@emeraldinsight.com

No part of this book may be reproduced, stored in a retrieval system, transmitted in any form or by any means electronic, mechanical, photocopying, recording or otherwise without either the prior written permission of the publisher or a licence permitting restricted copying issued in the UK by The Copyright Licensing Agency and in the USA by The Copyright Clearance Center. Any opinions expressed in the chapters are those of the authors. Whilst Emerald makes every effort to ensure the quality and accuracy of its content, Emerald makes no representation implied or otherwise, as to the chapters' suitability and application and disclaims any warranties, express or implied, to their use.

\section{British Library Cataloguing in Publication Data}

A catalogue record for this book is available from the British Library

ISBN: 978-1-80117-789-4 (Print)

ISBN: 978-1-80117-788-7 (Online)

ISBN: 978-1-80117-790-0 (Epub)

ISSN: 2043-9059 (Series)

\section{ISOQAR certified}

Management System,

awarded to Emerald

for adherence to

Environmental

standard

ISOQAR

ISO 14001:2004. 


\section{CONTENTS}

List of Figures

xiii

List of Tables

$x v$

List of Appendices

$x v$

About the Editors

xvii

About the Contributors

xix

Preface

xxiii

Acknowledgements

$x x i x$

Rethinking Finance in the Face of New Social, Societal and Environmental Challenges

David Bourghelle and Philippe Rozin

\section{PART I \\ FINANCE, FINANCIALISATION IN A GLOBAL \\ MARKET}

Introduction: Finance and Financialisation in a Global World

Yamina Tadjeddine

Financial Instability and Temporality Conflicts in Financialised

Capitalism

Renaud du Tertre

Unconventional Monetary Policies: New Normal or 'Black Hole'? 2019: The Year of Truth

Jacques Ninet

On the Financialisation of Business Strategies

Roland Pérez 
How Do We Counter Financialisation?

Paul Jorion

PART II

THE CONSTRUCTION OF FINANCIAL VALUES:

AN HISTORICAL PERSPECTIVE

Introduction: The Construction of Financial Values - A Historical

Perspective

Catherine Karyotis

Paving the Way towards Financialisation: The French Case of State Venality of Offices (Century 15th-17th)

Nicolas Pinsard

The Institutional Architecture of Value: Appraisals and the Formation of Bubbles in the Financialised Real Estate Sector Marine Duros

Accounting as a Political Object

Edouard Jourdain

\section{PART III}

SOCIAL REALITY AND THE NEW FINANCIAL STRUCTURES: SUSTAINABLE AND PARTICIPATORY FINANCE

Introduction: Responsible Finance and Social Impact - Assessing Alternative Forms of Social Engagement and Value Creation 145 Sharam Alijani

Social Impacts and Their Contracts

Florence Jany-Catrice and Marion Studer

The Crowdfunding: Towards a Commodification of Generosity? 167 Amélie Artis and Virginie Monvoisin

Sustainable Finance: Concepts, Analyses and Perspectives 181 Dhafer Saidane and Sana Ben Abdallah 


\section{PART IV \\ FINANCE, MARKETS AND SOCIETY: RETHINKING THE PARADIGM?}

Introduction: Finance, Markets and Society - Rethinking the Paradigm

Roland Pérez

Economics and Finance: The Monopoly and Dangers of the Mainstream School of Thought

Marc Chesney

Can Behavioural Finance Be the Foundation for New Regulation? 205 Sabrina Chikh and Pascal Grandin

Collective Affects and Speculative Bubbles in Financial Markets:

A Spinozist Perspective

David Bourghelle and Philippe Rozin

Teaching Finance through a Social Science Lens

Stéphanie Serve and Yamina Tadjeddine

Conclusion - Finance and Sustainability: An Integrated Thinking 257

Thomas Lagoarde-Segot, Roland Pérez and William Sun

Postscript

Michel Levasseur

Index 
This page intentionally left blank 


\section{LIST OF FIGURES}

Figure 1. Financial Conventions as Foundations of the Financial Accelerator and the Leverage Effect.

Figure 2. Financial Instability Sources in the Growth Regime of Financialised Capitalism.

Figure 3. Financial Cycles in the Euro Area.

Figure 4. The Leverage Effect in Non-financial Groups (NFG), Subject to Wide Cyclical Fluctuations (1993-2015).

Figure 5. The Three-component Breakdown of the Total Shareholder Return (TSR) of Non-financial Groups (NFG) (1993-2015).

Figure 1. Fed Funds Rate Tightening and Stock Market Performance 1957-2018.

Figure 2. Variation of Interest Rates (Fed Funds) and S\&P 500.

Figure 3. The Stock Market Fall at the End of the Tightening Cycle.

Figure 4. $\quad$ S\&P 500 Index September 2018-March 2019.

Figure 5. Statement of Fed Funds Rate Expectations. FOMC September 2014.

Figure 6. History of the Expectations of the Members of the Federal Reserve 2014-2019.

Figure 7. History of 3-Month Rate Expectations on Future Contracts.

Figure 8. Two Centuries of Inflation in the United States. 62

Figure 9. Two Centuries of Inflation in France. 63

Figure 10. Inflation (PCE) and Fed Funds Rate, Nominal and Real. 64

Figure 11. The Phillips Curve from the 1960s to the 2016-2017 Decade.

Figure 12. Total World Financial Assets 2007-2017.

Figure 1. The Circuit of Offices Allocation Taking the Form of State Venality with the Various Incomes Resulting from the Edict of Annual Right.

Figure 1. Expanded Global Performance: Efficiency, Productivity, Efficacy, Impacts.

Figure 2. Social Impact Bond Operation. 
Figure 1. The Different Phases of a Financial Bubble.

Figure 2. The dot.com Bubble (NASDAQ Index IXIC, 1994-2005).

The bubble of the South Sea Company: 1718-1721. 241

The roaring 1920's bubble and the Wall Street Crash. 242

The Japanese bubble: Nikkei index: 1970-2019. 242

The US real estate bubble.

243

The two Chinese bubbles: SSE composite index from 1992 to March 20, 2020.

The bitcoin bubbles.

Figure 1. The Decision-making Process in a Market Finance Service.

Figure 2. The Bank Credit Granting Process. 


\section{LIST OF TABLES}

Table 1. US Stock Exchange Behaviour during Monetary Tightening Cycles.

\section{LIST OF APPENDICES}

Appendix 1 For a Reform of Financial Training (R. Pérez in Paranque \& Pérez, 2016, pp. 134-135) 198

Appendix 1 The Phases of a Financial Bubble 240

Appendix 2 Examples of Famous Bubbles 241

Appendix 1 The Main Publications and Books by FAS Members and Partners

Appendix 2 PoCfiN Working Papers (since 2020) 
This page intentionally left blank 


\section{ABOUT THE EDITORS}

David Bourghelle is an Associate Professor at the University of Lille (IAE). He holds a PhD in Finance and an Accreditation to Direct Research (HDR) from the University of Lille. His teaching and research interests focus on financial markets, behavioural finance, the Efficient Market Hypothesis (EMH) and the role of institutions in Finance.

Roland Pérez has got a PhD in Economics (University Paris 1) and the French national concourse of University Professor in Economics and Management Science. He occupied several positions (CNRS, University of Amiens, CIHEAM, University of Montpellier) and became Emeritus Professor. Roland Pérez worked on corporate finance and strategic analysis.

Philippe Rozin is an Associate Professor at the University of Lille. He holds a $\mathrm{PhD}$ in Finance from the University of Paris, Nanterre, and a PhD in Philosophy from the University of Paris IV-Sorbonne. His field of research focusses on research and development, intangible assets and energy markets. 
This page intentionally left blank 


\title{
ABOUT THE CONTRIBUTORS
}

\begin{abstract}
Sharam Alijani is a Professor of Strategy and Entrepreneurship at NEOMA BS and a Researcher at HABITER Center at the University of Reims ChampagneArdenne. His teaching and research interests focus on social entrepreneurship, governance, innovation and sustainability studies. Dr. Alijani is an Editor of the Journal of Global Responsibility and the European Public Social Innovation Review and chairs the 'Finance and Economy for Society' track at EURAM. His research has appeared in international journals and books. Sharam serves on the board of AMU North America, a technology and impact investment gateway for social entrepreneurs.
\end{abstract}

Amélie Artis is an Assistant Professor at the Institut d'EtudesPolitiques de Grenoble since 2013 and a member of PACTE - CNRS. She has been conducting and leading research on the social and solidarity economy and financial issues for several years. She runs the Master 'Development et expertise de l'économie sociale'. Her research activities question the nature and role of SSE in current socio-economic changes. She is the Author of books and articles on the territorial approach of SSE and finance.

Sana Ben Abdallah is a PhD Student in Economics at Tunis Higher School of Commerce - University Of Manouba and is an Instructor at Faculty of Economic Sciences and Management of Mahdia (Tunisia). Her areas of interest include sustainable finance, corporate social responsibility, banking and finance. She has recently published academic papers in international and French journals

Marc Chesney is Professor, Director of the Department of Banking and Finance and Chair of the Center of Competence for Sustainable Finance at the University of Zurich. He holds a PhD in Finance from the University of Geneva and obtained his Habilitation from the Sorbonne University. His fields of research extend to financial crises and imbalances, systemic risks generated by financial innovation and global debt, globalisation and financialisation of the economy and environmental risks. He develops a critical analysis of the financial sector's role.

Sabrina Chikh holds a Doctorate in Finance (University of Lille) and is the Director of the MSc in Corporate Financial Management at Skema (Paris, Sophia, Belo Horizonte, Suzhou). Her area of research expertise is the effect of CEOs on the firm performance. She published studies in sustainable finance and won the SAB Trophy in 2014. She also co-wrote a book on behavioural finance (with Pascal Grandin, Finance Comportementale, Economica). 
Marine Duros is a PhD candidate in Sociology at the Centre Maurice Halbwachs (EHESS) and holds the agrégation of economic and social sciences (SES). Her doctoral research focusses on the process of financialisation of the real estate sector in France from the late 1980s onwards, based on an archival work, indepth interviews with professionals and a multi-site ethnography. She has published articles in the Revue française de socio-économieand Regards croisés sur l'économie.

Pascal Grandin is a Professor in Finance at the IAE Lille University School of Management and a member of the Lille University Management lab. His areas of expertise include portfolio management, market efficiency and behavioural finance. He has written several articles and books in these areas.

Florence Jany-Catrice is a Full Professor at the University of Lille, a member of the Research Center Clersé (UMR 8019) and a Richard B. Fisher Member, School of Social Science (2020-21), Institute for Advanced Study, Princeton. She works on the issues of the evaluation of public policies or on critics of the measurement of growth and inflation. She is currently working on the economy of quality. Her last publication is edited by Palgrave McMillan (2020) and entitled A Political Economy of the Measurement of Inflation.

Paul Jorion is an Associate Professor in the Department of Ethics, Technology and Transhumanism at the Universitécatholique de Lille. He holds a $\mathrm{PhD}$ in Social Anthropology and an MD in Sociology. He is a practicing Psychoanalyst. He was a contributor to the Connex artificial intelligence project of British Telecom. He was a Banker for 18 years in the United States, the United Kingdom, France and the Netherlands.

Edouard Jourdain is an Associate Researcher at EHESS. He holds a $\mathrm{PhD}$ in Philosophy and Political Sciences. He teaches at EcoleNationale des Ponts et Chaussée and Université Versailles Saint Quentin. His work focusses on religion, economy and politics, anarchism and Proudhon. His last book published is Theologie du capital (Presses Universitaires de France, Janvier 2021).

Catherine Karyotis, $\mathrm{PhD}$, HDR, is a Professor of Finance at Neoma Business School. She is the Head of the Master in International Financial Analysis and a Research Associate at LIRSA - CNAM Paris. Her teaching and research focus on bank and sustainable finance. She has published in international, academic and professional journals.

Thomas Lagoarde-Segot is a Professor of International Economics and Finance at KEDGE BS, where he served as an associate dean and a director of the doctoral program. Thomas currently supervises the Sustainable Finance of the French chapter of the UN's Sustainable Development Solutions Networks and the Post-Crisis Finance Network, an alliance of research chairs and academics created in 2018 by KEDGE BS and the Collège d'Etudes Mondiales (FMSH Paris). Thomas' current research focusses on sustainable development, postKeynesian economics and international finance. 
Michel Levasseur is a Graduate from HEC-Paris (1971), Docteur d'Etat Université Paris Dauphine (1976), Agrégé en sciences de gestion (1977). He taught successively within the group HEC-Paris, the Universities of Lille 1, Paris Dauphine, Lille 2 and the Universite catholique de Louvain. He is the author of numerous books in Finance (notably Finance: une approche responsable, Ed. Economica, 2015 and Gestion de portefeuille et marchés financiers, Ed. Pearson, 2013) and has published regularly in numerous French and international journals.

Virginie Monvoisin is an Associate Professor at the Grenoble École de Management. Her PhD dissertation was one of the first French theses on endogenous money and her research interests are in the areas of monetary economics, macroeconomics and economic systems. She works on the banking system and its alternative and ethic dimensions. Recently, she has co-coordinated the first state of art of post-Keynesian thought in French, 'L'économie post-keynésienne Histoire, théories et politiques'.

Jacques Ninet is a graduate of the ESCP-Europe Business school and shared his professional life between the financial markets and the University. He first held positions as Head of Finance at CEPME (today's BPI) and then led portfolio managers' teams of various Asset Management companies. He also served as a Research Director and as a Senior Research Advisor with the group La Française. As an Associate Professor in Finance, he has published many research papers about financial instability and assets bubbles and also contributed to Finance Reconsidered: New Perspectives for a Responsible and Sustainable Finance. Emerald CRGS vol 10, Wiley (2016). He has also published Negative Interest Rates: The Black Hole of Financial Capitalism, Emerald publication (2020).

André Orléan is an Economist. He is the Director of Studies at EHESS (School of Advanced Studies in Social Sciences) and Director of Research Emeritus at CNRS (National Center for Scientific Research). His research focusses on financial markets, the theory of money and the role of economic institutions. He has recently published The Empire of Value (MIT Press, 2014). He is also the Honorary President of the AFEP (French Association of Political Economy).

Nicolas Pinsard has a $\mathrm{PhD}$ in Economics. He is a member of the CEPN Department at the University of Sorbonne Paris Nord, France. His thesis is entitled 'Regulation and commodification of the state through taxation and finance. The case of offices in France between the 12th to the 17th century'. His work emphasises the causes behind the state's tendency to develop and reproduce itself as an institution. This work highlights the major role of the state during this transitive historical phase, which led to the capitalist mode of production. To that end, he is at the crossroads of the Regulation approach and socio-economic influence.

Dhafer Saidane has a PhD in Economics - HDR (Paris 1 - Sorbonne). He is a Full Professor at SKEMA Business School and a Director and Global Coordinator of the MSc 'Corporate Financial Management - FinTech and Digital 
Finance' in Suzhou (China), Belo Horizonte (Brazil), Paris, Sophia. He is a member of the Economic Analysis Council for the Tunisian Prime Minister. Expert in international institutions and advisor to the 'Club of African Bankers', Dhafer recently published 6 books including 'Sustainable Finance' (2011) and 'Banks and Finance in Africa: The Actors of Emergence' (Revue Banque edition, 2016).

Stéphanie Serve is a Full Professor at IAE Gustave Eiffel, UPEC (Université Paris-Est Créteil). She is a Researcher at Institut de Recherche en Gestion (IRG) and an Associate Researcher at Centre de Sociologie des Organisations, Science Po Paris. She holds a PhD in Finance, a Master of Science in Public Economy degree from the University of Paris I Pantheon-Sorbonne and a Master's degree from the HEC School of Management in Paris. Stéphanie's research focus includes public finance, corporate finance, accounting and economic sociology.

Marion Studer is a PhD student at the University of Lille and a member of the Research Centre Clersé (UMR 8019). She works on the evaluation issue in the social and cooperative economy, more precisely on the recent deployment of social impact measurement and its tools for financing by results, such as social impact bond.

Yamina Tadjeddine is a Full Professor of Economics at the Faculty of Law, Economics and Management, Université de Lorraine, and Research Fellow Beta, UMR CNRS 7522. Her research focusses on financial practices and financial regulation. She is a founding member of the Social Studies of Finance Association (http://ssfa.free.fr/). She has published scientific articles on financial economics and economic sociology of finance. She is the Author of several books and has co-edited with I. Chambost and M. Lenglet 'The Making of Finance', 2019. She teaches Banking Economics, International Financial Markets, Banking and Financial Regulation, Ethics and Finance.

Renaud du Tertre is an Emeritus Associate Professor at Université de Paris, Faculty of Humanities and Social Sciences, researcher at Ladyss. He worked as a Scientific Counsellor at the Commissariat Général du Plan, become France Stratégie today (2002-2008), and as Director of Studies at the Institut de Recherches Économiques et Sociales (IRES), an institute related to trade unions (2009-2010). His research focusses on uncertainty, price-making of capital assets, impact of finance on companies' strategy and on growth regimes of developed capitalist economies. 


\title{
PREFACE
}

\section{FINANCIAL VALUES AS SOCIAL FACT}

\author{
André Orléan
}

Since its origins, the question of value has been at the forefront of political economics and has been the focus of a constant theoretical debate on the part of economists. The approach that prevailed at the end of the nineteenth century, the so-called marginalist revolution, provides a fundamentally individualistic response in that it deduces the value of a commodity from the subjective assessments that individuals make of its usefulness. Consequently, from this perspective, individual preferences appear to be the elementary force that drives the entire economy: "Individual valuation is the keystone of economic theory... [The] essence and the driving force of human action, and therefore of the human market economy, are the valuations of individuals. Action is the result of choice among alternatives and choice reflects values, that is, individual preferences among these alternatives'. ${ }^{1}$ Within this marginalist concept of value, one hypothesis plays a crucial role: individual preferences must be, if not exogenous and fixed, at least independent of the prices they are supposed to explain. Otherwise, if preferences were dependent on prices, we would no longer know what explains what!

This same general framework of intelligibility has been used to analyse financial phenomena by substituting individual consumer preferences for subjective investor estimates of the value of securities. For it to be valid, this neoclassical approach to finance imperatively supposes that subjective estimates, like individual preferences, are independent of the prices they are supposed to explain. As far as goods are concerned, it is the existence of a perfectly defined product, whose quality is independent of price and known to consumers, which is the central institutional hypothesis for ensuring that preferences do not change in the course of trade, an imperative condition for the Walrasian analysis to be valid. Even if, in The Empire of Value, we presented a series of situations in which product quality and preferences are subject to variations in the course of trade (information asymmetries, reputational externalities, fashion phenomena), it can be argued that, in the general instance, for ordinary consumer and production goods, the independence hypothesis can be accepted. The situation is quite the opposite in the case of finance, due to the introduction of a specific reality, unknown to ordinary markets, namely liquidity, in other words, the possibility to renegotiate one's position at any given moment. 
Liquidity implies that each investor is, at all times, in constant contact with all other investors via the market, in such a way, as Keynes strongly emphasised in Chapter 12 of the General Theory, that

...the professional investor is forced to concern himself with the anticipation of impending changes, in the news or in the atmosphere, of the kind by which experience shows that the mass psychology of the market is most influenced. This is the inevitable result of investment markets organised with a view to so-called 'liquidity'. ${ }^{2}$

Consequently, liquidity produces what can be called a 'totalization effect' in the sense that it makes each participant so closely dependent on the group that he or she is forced to be on the alert at all times so as not to be surprised by shifts in collective opinion. This is the origin of short-termism. Such forced vigilance puts individual estimates under pressure, imposing frequent adaptations beyond what is necessary. To fully understand the artificial nature of the price movements thus generated, we refer once again to Keynes' Chapter 12 on the subject of liquidity:

In the absence of security markets, there is no object in frequently attempting to revalue an investment to which we are committed. But the Stock Exchange revalues many investments every day and the revaluations give a frequent opportunity to the individual (though not to the community as a whole) to revise his commitments. It is as though a farmer, having tapped his barometer after breakfast, could decide to remove his capital from the farming business between 10 and 11 in the morning and reconsider whether he should return to it later in the week. ${ }^{3}$

The origin of the phenomenon known as 'excessive volatility' should not be sought elsewhere. A similar phenomenon can be observed with 24-hour news channels. Being obliged to react every minute, journalistic commentary is forced to give importance to events that are in fact meaningless.

What this analysis highlights is what can be called the 'self-referential'4 nature of financial markets: individuals seek to anticipate the price, but the price itself is only the outcome of such anticipation. Consequently, the individualistic approach becomes inoperative insofar as individual estimates are as much a product of the financial markets as the price. In other words, the independence hypothesis no longer holds. One only has to think of financial bubbles to appreciate this, where we observe investors who are trying to follow a market that they fail to truly understand. Their usual valuation models become inoperative, ${ }^{5}$ so that everyone reacts as best they can to what appears to be a chaotic and irrational dynamic. We are then faced with the highly paradoxical and enigmatic reality of a market that has become autonomous, dominating individual investors, even though it is nothing more than the sum total of the individuals that make it up. 
It seems to me that this observation is at the heart of this book, Finance: Between Two Worlds. The book abandons the neoclassical world in favour of a new world that apprehends the financial market as an autonomous power of evaluation. The financial market is no longer viewed as a mechanism that passively records the estimates of one or another in order to aggregate them, but it is seen as an essentially normative mechanism that, through the interplay of a set of institutional devices, produces calculation formats that lead to the emergence of a price considered by all to be legitimate. Through this shaping event, and upstream of transactions, the market drastically reduces what would otherwise be the extreme diversity of subjective beliefs due to radical uncertainty. The work of Donald MacKenzie and Yuval Millo on the Black-Scholes formula has a paradigmatic value here. They show how the spread of this formula, despite all its intrinsic inadequacies, played an essential role in the constitution of options markets. It has led to the emergence of a common language that greatly facilitates the conduct of negotiations: 'Pricing models came to shape the very way participants thought and talked about options, in particular via the key, entirely model-dependent, notion of "implied volatility"" In the same vein, we should also mention the important work by Michel Callon and Fabian Muniesa. In this book, the examination of the real estate market by Marine Duros, the analysis of accounting standards by Edouard Jourdain and the study of asset management practices by Stéphanie Serve and Yamina Tadjeddine, among others, follow the same path to put forward convincing arguments.

What, in my view, is the fundamental issue at stake in all of these debates is the gradual elaboration of an entirely new conception of financial value as a social fact, radically breaking with the subjectivism of the marginalist approach. This is no mean feat when one considers that marginalism has reigned unchallenged over the economy for 150 years. In the approach sketched here, it is not individuals that produce value but the market itself as a social mechanism that amalgamates individual opinions and reworks and modifies them until it produces a valuation that is far more than the aggregation of individual estimates. This power of the market to create and impose a reference value is at the heart of reflections put forward in the chapter by David Bourghelle and Philippe Rozin. They call 'collective affect' the sui generis force that arises from the interactions generated by liquidity.

By way of conclusion, we should underscore the consistency of these reflections on financial value with the positions defended by Émile Durkheim on social values. Indeed, similar to our take on the financial market, Durkheim considers the group to have the power to produce judgements that are binding on all participants given the collective emotional investment they are the object of. As Célestin Bouglé, a close disciple of Durkheim, wrote: 'from the association of men emerges a force, endowed with a power of pressure as well as of attraction, and it is precisely this original force that we see at work in the world of values'. ${ }^{7}$ In countless passages in his many books, Durkheim insists on the power of assembled men to produce a new kind of psychic life, contrary to the laws of individual psychology: 
[T] he states of the collective consciousness are of a different nature from the states of the individual consciousness; they are representations of another kind. The mentality of groups is not that of individuals: it has its own laws. ${ }^{8}$

This is the very foundation of Durkheim's theory of social facts. We recognise here the same radically anti-reductionist position that characterises our analysis of the financial markets. This close proximity to the Durkheimian sociology of values is a very strong signal for all economists who consider that economics should not be separated from the social sciences. It is also what this book demonstrates in the fact that it sees anthropologists and historians, economists and management scientists, sociologists and political scientists as working in the same direction.

However, one point remains to be clarified: is the self-referential approach at odds with the sociological approach? This point, that we believe to be crucial, has been the focus of several debates ${ }^{9}$ and it is important to clarify the situation.

We may indeed object that the self-referential approach is constructed from a vision of the market identical to that put forward by neoclassical theory, namely, a set of elementary investors of equivalent weight, whereas, a contrario, the sociology of finance insists on the heterogeneity of the participants as well as the variety of institutional mechanisms brought into play. That is true, but it is by no means simply ineptitude. The self-referential approach deliberately seeks to confront mainstream economic thinking on its own ground. This should come as no surprise to anyone who keeps the Keynesian roots of this approach in mind. Indeed, the entire General Theory is conceived from this perspective and the gains of such a critical strategy cannot be neglected. This involves showing that, in a market dominated by liquidity, individuals tend to be interested, not in fundamental value, however it is defined, but in the opinion of the market, which is radically different. Thanks to the Keynesian beauty contest, the self-referential approach helps to establish the fact that financial speculation is in no way stabilising. All of these factors are criticisms of the omnipotence of the neoclassical edifice, using its own tools and its own language. It would be very naïve to think that this would be enough to produce a paradigm shift, but for those who keep in mind the major political role this argument has played in the constitution of financialised capitalism, they remain useful supporting forces.

However, the interest of the self-referential approach does not stop at this critical function alone. It has an intrinsic strength in that many aspects of the way financial markets function that escape the neoclassical framework are rendered intelligible, even if in an ideal-typical way. We can cite, among other things, the introduction of radical uncertainty; the critique of the objectivity of fundamental value; the link between liquidity and speculation; the role of financial conventions; the importance of mimicry and the critique of efficiency. But this approach alone cannot claim to produce all the intelligibility of the financial markets. Indeed, it has been shown that the property of salience ${ }^{10}$ plays a primordial role in determining what valuation the market agrees on in configurations of the Keynesian beauty contest type. However, salience is a highly contextualised 
notion: what a group considers salient depends on the historical experiences that have marked its memory. For Robert Shiller (1991), for example, we cannot understand the exceptional decline experienced by the New York market on 19 and 20 October, 1987, without including in the analysis the role played by the salience of the ' 1929 crisis' as a prototype of the stock market crisis. According to this economist, it was because investors interpreted the events of 1987 in the light of this prototype that they panicked. In other words, the self-referential approach calls for a sociological analysis as its necessary complement, which alone is capable of clarifying the models and conventions that, in the course of the history of a market, have become inevitable, as well as the devices through which they have spread. From this perspective, a self-referential and a sociological approach, far from being contradictory, support one another.

To fully understand this, we need only to consider Durkheim's exhibition logic. On the one hand, he continually insists that at the origin of values, we find the effervescence of human groups. 'The great ideals upon which civilisations rest' emerge from the interaction of individual consciences (Durkheim, 1911/1953). If he attaches so much importance to this ideal-typical model, it is because it allows him to spell out the nature of social facts. This is not insignificant. However, it would not occur to Durkheim to use this model to try to elucidate, for example, revolutionary ideals on the basis of an aggregation of the opinions of members of the revolutionary assembly! On the contrary, as for us, this ideal-typical model is used to put forward the radical solution of continuity that exists between individual beliefs and collective representations. Therefore, when social facts need to be explained, its principle is: 'The determining cause of a social fact must be sought among antecedent social facts and not among the states of the individual consciousness'. ${ }^{11}$ We can say that with the notion of salience, the economic approach becomes aware of its incompleteness and recognises the need for new tools and new concepts borrowed from sociology. Our hope is that, in so doing, this book will provide the basis for a new alliance between economics and social science that is all the more robust as it is based on a common conceptual approach to financial value.

\section{NOTES}

1. Rothbard (1956, p. 1).

2. General theory (1936/1964, p. 155).

3. General theory (1936/1964, pp. 150 and 151).

4. The empire of value (2014), Part III, pp. 175-238.

5. Trueman, Wong, and Zhang (2000).

6. MacKenzie and Millo (2003, p. 137).

7. Bouglé (1926, personal translation).

8. Durkheim (1895/1982, p. 39).

9. For example, Lazarus (2015).

10. See Section 'Self-referentiality and Conventional Belief' in The empire of value (2014), 211-220.

11. Durkheim (1895/1993, p. 134). 


\section{REFERENCES}

Bouglé, C. (1926). The evolutions of values; studies in sociology with special applications to teaching. New York, NY: Henry Holt.

Durkheim, E. (1895/1982). The rules of sociological method [S. Lukes (Ed.) and W. D. Halls (trans.)]. New York, NY: Free Press.

Durkheim, E. (1911/1953). Value judgments and judgments of reality. In Sociology and philosophy [D. F. Pocock (trans.)] (pp. 80-97). Glencoe, IL: Free Press.

Keynes, J. M. (1936/1964). The general theory of employment, interest and money. London: Macmillan.

Lazarus, J. (2015). La finance et la vérité des prix. La Vie des Idées. Paris: Collège de France. Retrieved from https://laviedesidees.fr/spip.php?article3187

MacKenzie, D., \& Millo, Y. (2003). Constructing a market, performing theory: The historical sociology of a financial derivatives exchange. American Journal of Sociology, 109, 107-145.

Orléan, A. (2014). The empire of value. Cambridge, MA and London: The MIT Press.

Rothbard, M. N. (1956). Toward a reconstruction of utility and welfare economics. In M. Sennholz (Ed.), On freedom and free enterprise (pp. 224-262). Princeton, NJ: D. Van Nostrand Company.

Shiller, R. (1991). Investor behavior in the October 1987 stock market crash: Survey evidence. In R. Shiller (Ed.), Market volatility (pp. 379-402). Cambridge, MA and London: The MIT Press.

Trueman, B., Wong, M. H. F., \& Zhang, X.-J. (2000). The eyeballs have it: Searching for the value in internet stocks. Journal of Accounting Research, 38, 137-162. 


\section{ACKNOWLEDGEMENTS}

This book originates from a finance symposium organised in Lille (France) in July 2019.

We would like to extend our warmest thanks to all the people and institutions that made it possible to hold the initial meeting in the best possible conditions and to produce the editorial programme leading to this publication. Special thanks go to

- Florence Jany-Catrice, Chair of AFEP (Association Française d'Economie Politique) who hosted our financial symposium in the international conference organised with the IIPPE (International Initiative for Promoting Political Economy).

- William Sun, partner of the international programme 'Finance and Sustainability' (FAS), from its inception in 2009, a colleague who agreed to include this book in the series he edits at Emerald Publishing 'Critical Studies on Corporate Responsibility, Governance and Sustainability'.

- The members of the workshop's organising and scientific committees together with all the authors and debaters.

- André Orléan for agreeing to write a preface and Michel Levasseur for the postscript.

- Yamina Tadjeddine, Catherine Karyotis and Sharam Alijani for the introductions to the different parts of the book and Thomas Lagoarde-Segot for his contribution to the conclusion.

- The Rime Lab (Recherche Interdisciplinaire Management Economie, EA 7396) for its institutional and financial support.

http://serveur-web.iae.univ-lille1.fr/SitesFormations/rimelab/index.php

And finally, thanks to Susan Leclercq for proofreading our work.

Lille, December 2020

David Bourghelle

Roland Pérez

Philippe Rozin 
This page intentionally left blank 


\section{RETHINKING FINANCE IN THE FACE OF NEW SOCIAL, SOCIETAL AND ENVIRONMENTAL CHALLENGES}

\section{David Bourghelle and Philippe Rozin}

The contributions in this book are from a workshop held from 3 to 5 July 2019 at the Institut d'Etudes Politiques in Lille, organised as part of the AFEP/IIPPE colloquium. The guiding theme of the meeting was Rethinking finance in the face of new social, societal and environmental challenges.

This scientific meeting was well before the global pandemic, known as the Covid 19, which seemed to appear in China in the end of 2019 and spread - as is well known - to the entire planet during the year 2020. To date, it is not yet possible to predict with any certainty how the world economy, which has been severely affected by the measures taken by the various states concerned to deal with this pandemic, will be able to recover. Nor is it known whether other comparable or even larger-scale disasters will not occur in the coming years, as the current situation is more than ever a result of the 'radical uncertainty' referred to by J/M. Keynes (A Treative on Probability, London, McMillan, 1921). The guiding theme of the July 2019 symposium in Lille has, without wishing to do so obviously, anticipated a collective reflection on the need for 'Rethinking finance in the face of new social, societal and environmental challenges'.

The colloquium provided an opportunity to highlight the link between the growing reduction in the explanatory power of economic theory - conventionally referred to as 'standard', 'orthodox' or 'mainstream' economics - and the frequency of the systemic crises that world economies are currently going through (financial crisis, social crisis, ecological crisis...). Beyond the ideological cleavages dominating the field of economic research, the aim was to understand the new agenda structuring the economic world of the future. Critical distance from a highly dogmatic approach underpinned the driving force and deep motivation

\footnotetext{
Rethinking Finance in the Face of New Challenges Critical Studies on Corporate Responsibility, Governance and Sustainability, Volume 15, 1-6 Copyright (C) 2021 David Bourghelle and Philippe Rozin Published under exclusive licence by Emerald Publishing Limited ISSN: 2043-9059/doi:10.1108/S2043-905920210000015002
} 
behind most of these contributions. Many orthodox models, never previously called into question, have, in fact, demonstrated their capacity to ignore, through standard and often stereotyped reasoning, the major changes affecting the way in which the sciences, and particularly the social sciences, apprehend, analyse, conceptualise and formalise economic facts.

Within this scientific field and despite the sometimes extremely sharp and profound shocks generated by deregulation of the economic and financial spheres in recent decades, standard financial theory is specific in that it constitutes a selfsufficient - and self-referential - body of doctrine which claims to develop instruments that are resolutely practical in scope. Predictive in its pretensions, while integrating a restrictive conception of the rationality of economic agents, this theory, with all of its various branches, is clearly marked by its propensity to develop instruments of quantification, rationalisation and intelligibility for numerous financial facts. However, although enriched by decades of conceptual work, advanced modelling and increasingly precise empirical investigations, some of its hypotheses have been the object of serious criticism for many years, so the approach has never taken seriously.

Orthodox financial theory postulates a representation of the world based on the concept of objective and calculable values. These values have been absorbed into a model of world representation that problematically saturates reality. Objectivating an equilibrium state as a normative horizon, the standard financial model supports the idea, for example, that financial competition produces 'fair' prices, metrics that provide reliable signals to investors and efficiently guide asset allocation choices. In so doing, the approach ignores the psychological biases, beliefs and collective representations of the actors that populate markets and organisations (factors whose documentation and empirical input that take a realistic, situated rationality into account are acknowledged as long-standing scientific achievements).

However, heterodox approaches that are alternatives to standard theory offer innovative conceptual frameworks, able to give a different perspective (behavioural finance, financial convention theory, regulation theory, sustainable finance, social studies of finance, etc.). These theories reaffirm the importance and the role of psychology, collective processes and institutions as instances for determining the behaviour of agents. More pragmatic, they do not ignore the importance of actors' rationality when decisions are made, but take note of the fact that their actions are part of a state of collective structures and externalities, with a level of interdependencies which largely determine their behaviour and their value representations.

Financial decision-making processes modelled on the basis of cognitive forms (all of which are largely tainted by behavioural biases or dictated by common affects), the transformation of accounting, financial and managerial tools with regard to financial markets expansion, and even new governance strategies within organisations and markets all appear as new fields of investigation, requiring the theoretical formulation of a new conceptual structure which is still in limbo.

The aim of this book is, thus, to provide an overview of the new research perspectives devoted to financial activity as a corporate goal. The 14 
contributions reconsider the opposition between orthodox and heterodox schools of finance. The aim is not only to identify new theoretical and practical issues around the concepts of values, radical uncertainty and financial instability but also to examine the consequences of the financialisation process on the dynamics of organisations and markets, as well as on value production mechanisms.

The first part is devoted to the globalisation and financialisation of economies, central banks and corporate strategies. Analysis of the unprecedented expansion of the financial sphere and the way it has developed from the diffusion of specific models with strong performative virtues allows us to apprehend the stakes of economic financialisation, an irresistible process, constantly demonstrating its imperious power and claiming a transparency and objectivity that any alternative coordination effort could never achieve. The construction of an ideal model, based on the unlimited circulation of liquidity, has obvious normative pretensions. However, the financial deregulation and market financialisation processes are legitimised by an ideological system with no solid scientific basis. Adopting different and complementary scales of observation of the characteristics of a system, which could be described, as Lordon put it, as 'financial-dominated deregulatory capitalism', the contributions presented in this section allow us to grasp, each in their own way, how the deregulated structures of market finance have increased the instability inherent in financialised capitalism and generated major temporal conflicts between the long financial cycle, the economic cycle and short-term fluctuations in stock prices (R. du Tertre, Chapter 1). ${ }^{1}$ The structural disorders of the globalised economy and the process of financial deregulation have also steadily led the financial markets to take control of monetary policies. As a result, the 'singularity' of establishing a 'permanent unconventional monetary regime' has gradually become apparent, notably in the form of permanently negative or zero interest rates and increasingly extensive quantitative easing strategies (J. Ninet, Chapter 2). These changes have also spurred a movement towards the financialisation of corporate governance and strategic decisions in recent decades (massive share buybacks, highly leveraged financial structures) and, in so doing, have accelerated the process of capturing shareholder value (R. Pérez, Chapter 3). The consequences of these transformations in financial structures extend much further. They have ultimately led to the emergence of globalised rent systems and produced uncontrollable speculative dynamics that only binding legislative provisions, or even outright prohibition, could still curb (P. Jorion, Chapter 4).

Against this backdrop, the issue of liquidity and the conventional processes for valuing financial assets deserve to be re-examined from a historical perspective. The second part of this book focuses on financial value as a historically situated social construct. The theological angle in medieval times is particularly enlightening here. The venality of the offices and the creation of 'secondary' markets intended to provide them with an exchange value, offer a striking example of the financialisation of a divine good, a financialisation emanating from the political order itself, but which will subsequently be affected by its own creation (N. Pinsard, Chapter 5). This question of liquidity is also relevant when looking at other asset classes (notably real estate) that are already largely dependent on 
artificial liquidity and are, in fact, subject to significant price distortions. In the context of a radical uncertainty about the future, the construction of real estate value is the outcome of power relations between agents gathered into hierarchical professional organisations, and invested in the work of legitimising the arbitrariness of value through codified rituals (M. Duros, Chapter 6). Book value is also subject to the influence of financial market activity. Far from being the preserve of specialists claiming to be scientifically neutral, accounting valuation conceals highly normative choices. With the advent of the International Financial Reporting Standards (IFRS), the global financial infrastructure has definitively ratified an asset value accounting model that is now in force in global markets, and which is a political object in itself, and a powerful instrument of corporate governance and submission to the 'empire of value' (E. Jourdain, Chapter 7). ${ }^{2}$

The third part of the book examines the relationship between finance, social value and sustainable development. In this respect, the persistent question of the social utility of finance continues to crop up. By reinvesting entire social fields and transforming them into a new value matrix, financial markets are now emerging as a remarkably constructed response to issues that were apparently structurally external to them. This is the case regarding the evaluation practice of projects with a social impact, conducted by various actors (governments, local authorities, social and solidarity economy (SSE) enterprises). By including 'financial value' among the determinants of public action, the social impact contracts (bonds issued by public actors, or SSE, raised from private investors) provide a particularly enlightening illustration of the emergence of a new mode of evaluation and social action regulations (F. Jany-Catrice and M. Studer, Chapter 8). A similar analysis can be made of the development of donation-based crowdfunding. Initially intended to draw donors and recipients closer together to facilitate the development of projects with a social and/or environmental purpose, these platforms encourage the monetisation of expenditure and projects, and the marketisation of donation activities. In this sense, far from being an alternative and a counter-model to traditional finance, crowdfunding has become a financialisation tool that profoundly changes the nature of social relations (A. Artis and V. Monvoisin, Chapter 9). Alternatively, creating a different approach to social and ecological values requires the development of a research programme with broad ambitions. In recent years, many researchers have been working on an ambitious programme devoted to sustainable development goals (SDGs). From this perspective, the debate on sustainable finance, consisting in particular of providing the means to support corporate social responsibility (CSR) and socially responsible investment (SRI), is undergoing unprecedented acceleration, encouraged by the context of the ecological and health crisis that the world has been experiencing since the beginning of 2020, but also by the development of digital technologies (D. Saidane and S. Ben Abdallah, Chapter 9).

The fourth part of the book aims to present a number of avenues for reflection with a view to a paradigmatic renewal of research and teaching in finance. Indeed, the various contributions included in this book provide the reader with an ambitious programme of renewed concepts, hypotheses and practices. Out of touch with the needs and realities of the economy and society, orthodox 
economists have still not learned the lessons of the 2008 financial crisis. Now, we need to truly take on board the impasses of mainstream financial theory, the dangers of deregulated markets in a globalised world and the misdeeds of the outrageous mathematisation of the tools and teaching of finance. In this respect, it is vital that questions relating to ethics, sustainable development and the Commons make a strong entry into the curricula of management and financial economics textbooks (M. Chesney, Chapter 11). However, this will require renewing the paradigm of optimistic rationality which still structures many research agendas in Economics and Finance today. Alternatives exist and are developing at a significant pace. The field of research devoted to behavioural finance appears ripe for a paradigm shift. The original analysis of financial concepts and decisions, which it meticulously incorporates, seems very promising. However, even if the identification of cognitive biases, whose heuristics are tainted by financial actors, legitimately leads the authorities to propose revisions of financial regulations, it would seem that many of the anomalies highlighted in the literature are beyond the reach of the regulator (P. Grandin and S. Chick, Chapter 12). A more radical conceptual approach could provide a serious alternative to neo-classical financial theory. This involves entirely reconsidering financial value as a social fact. Unable to make an objective assessment of a radically uncertain future, financial market participants are reduced to conjecture, producing possible scenarios and making heterogeneous judgements about the future. How is financial value then determined? The initial observation is that it is not the result of the simple aggregation of individual estimates but is a market output. Price dynamics are driven by a common affect endowed with autonomous power, the power of the multitude, based on 'the unison of the group's desires', or what Durkheim calls a collective feeling. The theory of common affect, developed by Spinoza, can help us to understand the mechanisms of the production of collective emotions in financial markets, providing powerful conceptual resources to understand the speculative dynamics at the origin of the great financial bubbles (D. Bourghelle and Ph. Rozin, Chapter 13). Marking a major comeback of the social sciences in economic analyses, these lines of research also offer the potential for a large-scale epistemological mutation, including in corporate and market finance teaching practices. Complementing the hypothetico-deductive approach that is so widespread in mainstream economic science, the application of inductive methods, based on the observation of real facts and in-depth analysis of the institutional arrangements at the origin of value production, will undoubtedly lead to a more comprehensive pedagogical experience, quite different from the ideological paiedia specific to neo-classical theory (Y. Tadjjedine and S. Serve, Chapter 14).

At a time when an unprecedented infectious and sanitary crisis (resulting from the massive and accelerated spread of a pandemic that emerged from the ecological inconsequence of humanity) is generating disastrous financial, economic, social and societal repercussions, we can affirm without hesitation that all the questions about the capacity of our academic disciplines to offer a conceptual lens that could shed light on past crises and, above all, protect us from future crises, will remain, in the months and years to come, of absolute relevance. Our 
hope is that the work presented in this book will stimulate reflection and contribute to the renewal of a finance that now has to face many new social, societal and environmental challenges.

\section{NOTES}

1. Lordon. F After the financial crisis: 'regulate' or recast? The inadequacies of prudential strategies, Revue de la Régulation, 5 | 1st semester/Spring 2009: Crisis of financial capitalism.

2. Orléan, A. (2014). The empire of value. Cambridge, MA and London: The MIT Press. 


\section{PART I}

FINANCE, FINANCIALISATION IN A GLOBAL MARKET 
This page intentionally left blank 